\title{
Analysis The Effect of Coconut Shell Charcoal Mixed Doses and Adhesive In Characteristics Jamu Dregs Briquettes
}

\author{
(Analisis Pengaruh Dosis Campuran Arang Tempurung Kelapa Dan Bahan Perekat Pada \\ Karakteristik Briket Ampas Jamu)
}

\author{
Arinda Dwi Arafah, Soni Sisbudi Harsono*) \\ Jurusan Teknik Pertanian, Fakultas Teknologi Pertanian Universitas Jember \\ Jln. Kalimantan 37, Jember 68121
}

\section{ABSTRACT}

Briquette is an alternative simple fuel that has a relatively high calorific value, so it has the potential to reduce the use of firewood and fuel oil (BBM). Herbal waste is one of the biomass materials that came from the rest of the material in the production of herbal medicine made from medicinal plants. Utilization of herbal dregs as briquettes has been implemented by PT. Industri Jamu dan Farmasi Sido Muncul. Tbk, as fuel for boiler engines. Making briquettes from biomass requires the addition of materials, one of which is coconut shell charcoal and adhesives such as molasses and tapioca flour to improve the physical properties of the briquettes. Briquettes with good quality have a maximum moisture content and ash content of $8 \%$, a heating value of more than $5000 \mathrm{cal} / \mathrm{gram}$, a constant combustion temperature of $350^{\circ} \mathrm{C}$ for a long period of time and is easily flammable. The purpose of this study was to determine the characteristics of briquettes based on the value of water content, ash content, combustion temperature, combustion rate, and calorific value. Variable treatment with the addition of coconut shell charcoal with several doses of $10 \%$, $20 \%$, and $30 \%$ and variations of adhesive materials. Data analysis was performed by using two-factor ANOVA statistical test. The results showed that briquettes with tapioca flour adhesive and 30\% coconut shell charcoal composition had the best characteristics of briquettes compared to other variations.

Briket merupakan salah satu bahan bakar alternatif yang sederhana dan memiliki nilai kalor yang relatif tinggi, sehingga pengembangannya berpotensi untuk mengurangi penggunaan kayu bakar dan bahan bakar minyak (BBM). Ampas jamu merupakan salah satu bahan biomassa yang berasal dari sisa material pada produksi jamu yang terbuat dari tanaman obat. Pemanfaatan ampas jamu sebagai briket sudah diimplementasikan oleh PT. Industri Jamu dan Farmasi Sido Muncul. Tbk, sebagai bahan bakar mesin boiler. Pembuatan briket dari biomassa diperlukan penambahan bahan salah satunya yaitu arang tempurung kelapa dan bahan perekat seperti molases dan tepung tapioka untuk meningkatkan sifat fisik dari briket. Briket dengan kualitas baik memiliki nilai kadar air dan kadar abu maksimal 8\%, nilai kalor lebih dari $5000 \mathrm{kal} /$ gram, suhu pembakaran yang tetap $350^{\circ} \mathrm{C}$ dalam jangka waktu yang cukup panjang dan mudah terbakar. Tujuan dari dilakukanya penelitian ini adalah untuk mengetahui karakteristik briket berdasarkan nilai kadar air, kadar abu, suhu pembakaran, laju pembakaran, dan nilai kalor. Variabel perlakuan dengan penambahan arang tempurung kelapa dengan beberapa dosis yaitu 10\%, 20\%, dan 30\% dan variasi bahan perekat. Analisis data dilakukan dengan uji statistika ANOVA dua faktor. Hasil penelitian menunjukkan bahwa briket dengan perekat tepung tapioka dan komposisi arang tempurung kelapa 30\% memiliki karakteristik briket terbaik dibandingkan dengan variasi yang lain.

Keywords: briquettes, herbal dregs, coconut shell charcoal, tapioca flour, molasses.

*)Corresponding author:

Soni Sisbudi Harsono

E-mail: s_harsono@unej.ac.id

\section{PENDAHULUAN}

Briket merupakan bahan bakar alternatif yang sederhana, baik dari segi proses pembuatan maupun penggunaan bahan baku pembuatan briket, sehingga memiliki potensi yang cukup besar untuk dikembangkan. Penggunaan bahan bakar briket dapat mengurangi penggunaan kayu bakar dan BBM, hal ini 
dikarenakan briket memiliki nilai kalor yang relatif tinggi dengan lama pembakaran yang panjang. Proses pembuatan briket banyak menggunakan bahan baku yang berasal dari biomassa. Menurut Suhartoyo dan Sriyanto [1], biomassa merupakan istilah untuk menggambarkan jenis material organik yang dihasilkan dari proses fotosintesis. Sumber energi jenis biomassa dapat diperoleh dari limbah hasil pertanian, perkotaan, industri maupun pertanian.

Menurut Ismayana dan Afriyanto [2] ketersediaan biomassa di Indonesia yang melimpah berpotensi menjadi sumber energi alternatif untuk mengurangi penggunaan energi fosil yang ketersediaanya terus menipis. Salah satu jenis biomassa yang dapat dimanfaatkan menjadi briket ialah ampas jamu. Ampas jamu merupakan salah satu bahan biomassa yang berasal dari sisa material pada produksi jamu yang terbuat dari tanaman obat seperti kunyit, kencur, jahe, temulawak, dan berbagai macam jenis tanaman obat lainya. pemanfaatan ampas jamu menjadi bahan bakar telah diimplementasikan oleh PT. Industri Jamu dan Farmasi Sido Muncul Tbk untuk bahan bakar mesin boiler yang perharinta PT. Sido muncul menghasilkan 40 ton ampas jamu, penggunaan briket ampas jamu dinilai lebih ramah lingkungan dan memiliki nilai kalor yang cukup tinggi (PT. Sido Muncul, 2020) [3]

Pembuatan briket dari biomassa biasanya memerlukan penambahan bahan untuk memaksimalkan nilai kalor pada briket salah satunya ialah arang tempurung kelapa menurut Budi 2011 [4] salah satu pemanfaatan arang tempurung kelapa dapat dijadikan sebagai bahan bakar arang yang dapat diolah lebih lanjut seperti briket hal ini dikarenakan 74,3\% kandungan dari tempurung kelapa berupa karbon sehingga dapat menhasilkan nilai kalor yang tinggi Penambahan bahan perekat untuk meningkatkan sifat fisik pada briket. Menurut Ristianingsih et al [5] penambahan bahan perekat yang sesuai akan meningkatkan nilai kalor, kerapatan, ketahanan tekan, kadar air, kadar abu briket tersebut. Bahan perekat yang biasa digunakan pada pembuatan briket adalah tepung tapioka dan molases yang merupakan jenis perekat organik.

Briket dengan kualitas yang baik berdasarkan SNI 01-6235-2000 [6] memiliki nilai kalor yang lebih dari $5000 \mathrm{kal} / \mathrm{gram}$, nilai kadar abu maksimal 8\%, nilai kadar air maksimal 8\%. Menurut Lubis et al [7] karakteristik briket yang baik memiliki nilai suhu pembakaran briket yang tetap $350^{\circ} \mathrm{C}$ dalam jangka waktu yang panjang dan mudah terbakar.

\section{METODE PENELITIAN}

\section{Bahan Penelitian}

Bahan yang digunakan pada penelitian ini adalah ampas jamu yang berasal dari tanaman obat, arang tempurung kelapa (daerah Jember), tepung tapioka 99, dan molases (PG. Pandjie Situbondo).

\section{Alat Penelitian}

Alat yang digunakan pada penelitian ini adalah satu set alat cetak briket dan pengempa Hydraulic Press 10 Ton Wipro, alat pengkarbonisasi, timbangan analitik, ayakan mesh 60, tungku briket, thermometer, stopwatch, oven, desikator, laptop, bom kalori meter, furnace, dan gelas ukur $50 \mathrm{ml}$.

\section{Prosedur Penelitian}

Ampas jamu yang sudah dikeringkan dikarbonisasi selama kurang lebih 1-2 jam hingga terkarbonisasi secara sempurna. Arang yang diperoleh kemudian diayak menggunakan ayakan mesh 60 agar memiliki ukuran yang seragam dan memudahkan proses pencetakan briket. Pembuatan perekat divariasikan menggunakan tepung tapioka dan molases sebanyak 10 gram pada masing - masing perekat, pembuatan perekat dilakukan dengan cara mencampurkan bahan perekat dengan air yang sudah dipanaskan sehingga tekstur perekat akan berubah lebih mengental. Arang ampas jamu dicampurkan dengan arang tempurung kelapa yang sudah di ayak dengan ayakan mesh 60 dengan variasi dosis arang tempurung kelapa 10\%, $20 \%$, dan 30\% dari berat total briket, kemudian mencampur arang dengan perekat tepung tapioka dan molases . arang yang sudah tercampur dengan perekat dicetak dengan alat pencetak briket. Hasil briket yang sudah dicetak dengan metode oven pada suhu $75^{\circ} \mathrm{C}$ selama 9 jam bertujuan untuk mengurangi kadar air pada briket. Pengujian karakteristik briket berdasarkan nilai kadar air, nilai kadar abu, nilai kalor, suhu pembakaran, dan laju pembakaran. Analisi data penelitian dilakukan dengan uji ANOVA dua arah yang bertujuan untuk mengetahui pengaruh jenis perekat dan dosis arang tempurung kelapa terhadap karakteristik briket. 


\section{HASIL DAN PEMBAHASAN}

\section{Kadar Air}

Kadar air merupakan parameter yang menghitung banyaknya air pada suatu bahan, semakin banyak kadar air yang terkandung dalam briket akan berpengaruh pada kualitas, nilai kalor dan suhu pembakaran briket yang rendah serta daya simpan briket akan singkat (Yuliah et al.) [8] . Grafik kadar air briket dapat dilihat pada Gambar 1.

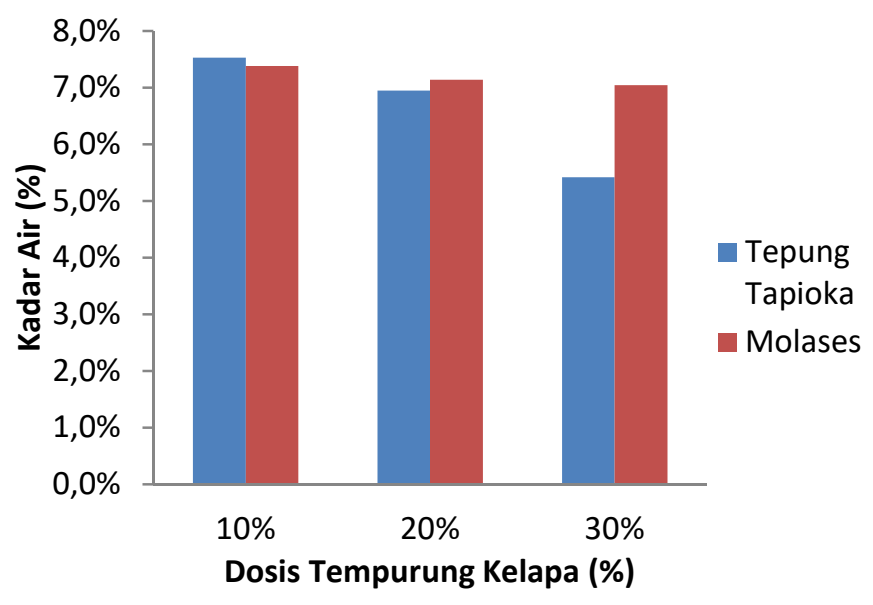

Gambar 1. Grafik kadar air briket

Pada Gambar 1 dapat diketahui briket dengan nilia kadar air tertinggi pada briket perekat tepung tapioka dan dosis arang tempurung kelapa 10\% sebesar 7.5\%, dan terendah pada briket perekat tepung tapioka dan dosis arang tempurung kelapa 30\% sebesar 5,4\%. Perbedaan nilai kadar air dapat disebabkan oleh perbedaan jenis bahan perekat, menurut Kurniawati et al [9], jenis perekat tapioka memiliki kandungan pati yang lebih besar dibandingkan perekat molases, sehingga briket dengan perekat tepung tapioka memiliki kerapatan yang lebih tinggi dan pori-pori briket akan semakin kecil. Menurut Faijah et al [10] kandungan pati pada tepung tapioka tersusun dari dua macam karbohidrat, yaitu amilosa dengan kadar $12,28 \%$ - 27,38\%, amilosa memberikan sifat keras dan amilopektin dengan kadar 72,61\% - 87,71\% akan memberi sifat sifat lengket yang optimal.

\section{Kadar Abu}

Pengujian kadar abu briket untuk mengetahui bagian briket yang tidak memili unsur karbon. Nilai kadar abu briket dipengaruhi oleh adanya kadungan bahan anorganik pada yang dapat berpengaruh buruk pada nilai kalor briket (Kurniawati et al.) [11]: Grafik kadar abu briket dapat dilihat pada Gambar 2.

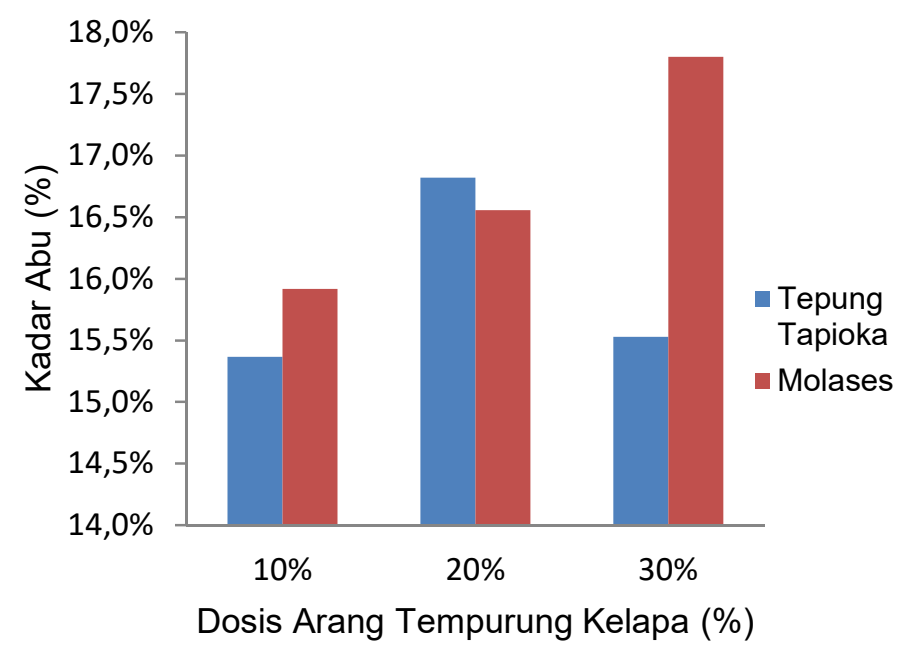

Gambar 2. Grafik kadar abu briket

Berdasarkan Gambar 2 dapat diketahui nilai kadar abu tertinggi pada briket dengan perekat molases dan dosis arang tempurung kelapa 30\% sebesar 17,8\%, kadar abu terendah pada briket dengan perekat tepung tapioka dan dosis arang tempurung kelapa 30\% sebesar 15,5\%. Menurut Pane et al. [12], nilai kadar abu pada arang tempurung kelapa sebesar 13,08\% lebih besar dibandingan dengan nilai abu pada tempurung kelapa yang hanya 3,58\%. Jenis perekat dapat meningkatkan nilai kadar abu pada briket, selain itu juga dapat disebabkan faktor lain seperti pengotor berupa mineral yang tidak dapat terbakar atau dioksidasi oleh oksigen, pengeringan bahan yang tidak homogen, dan pengotor dari eksternal dari lingkungan saat proses pembuatan briket (Ristianingsih et al.) [13].

\section{Laju Pembakaran}

Laju pembakaran briket merupakan kecepatan briket habis menjadi abu dengan berat tertentu yang bertujuan untuk mengetahui efektifitas dari briket dan kelayakan dari briket yang di uji hingga dapat digunakan. Grafik laju pembakaran dapat dilihat pada Gambar 3. 


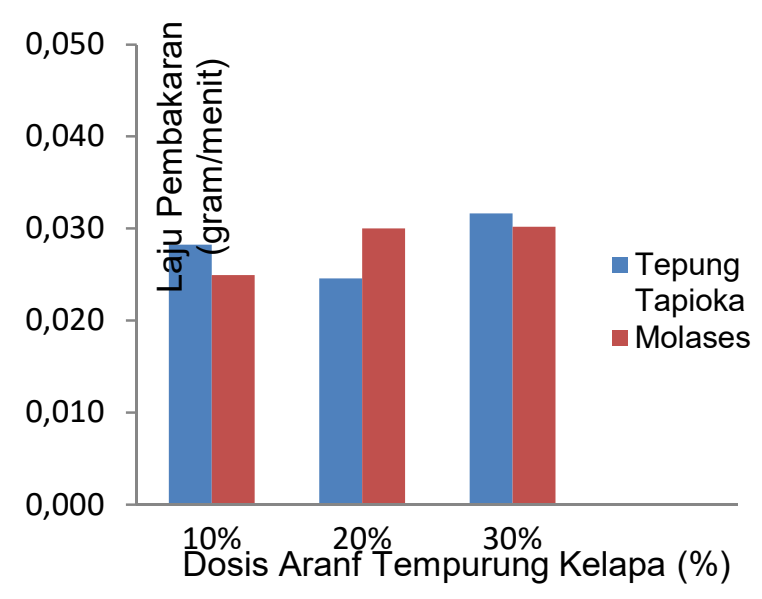

Gambar 3. Grafik laju pembakaran briket

Berdasarkan Gambar 3. Dapat diketahui nilai laju pembakaran tertinggi pada briket dengan perekat tepung tapioka dan dosis arang tempurung kelapa $30 \%$ sebesar $0,032 \mathrm{gram} / \mathrm{menit}$, laju pembakaran terendah pada briket perekat molases dengan dosis arang tempurung kelapa 10\% sebesar $0,025 \%$ dan perekat tepung tapioka dengan dosis arang tempurung kelapa 20\% sebesar $0,025 \%$. Laju pembakaran briket dapat dipengaruhi oleh beberapa faktor yaitu nilai kalor, kadar air, struktur bahan, kandungan karbon terikat dan tingkat kekerasan bahan pada briket (Rahmadani) [14].

\section{Suhu Pembakaran}

Pada proses pembakaran, briket akan menghasilkan panas dengan nilai yang berbeda-beda tergantung pada bahan yang digunakan pada pembuatan briket. Hasil uji suhu pembakaran dapat dilihat pada Gambar 4.

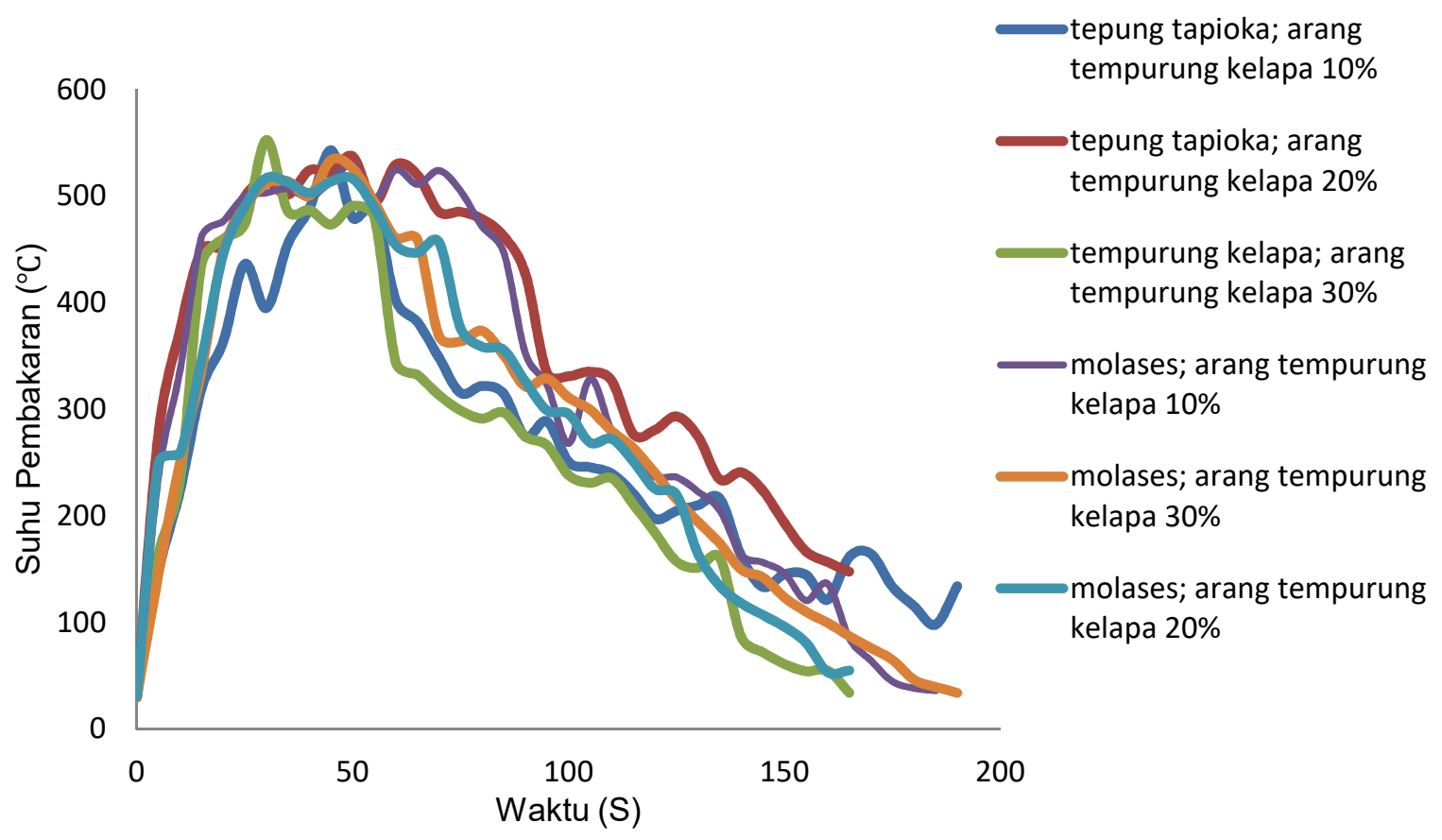

Gambar 4. Grafik suhu pembakaran briket

Berdasarkan Gambar 4 diketahui suhu pembakaran briket tertinggi pada semua variasi berada pada rentang suhu $538-553{ }^{\circ} \mathrm{C}$, suhu pembakaran briket memiliki suhu maksimal yang tinggi dan sesuai dengan persyaratan suhu maksiman briket antara $300-500{ }^{\circ} \mathrm{C}$ (Nuracman dalam Ismayana)[15]. Menurut Jamilatun (2008)[16], suhu pembakaran briket yang tinggi menyebabkan kenaikan pada laju reaksi pembakaran serta waktu pembakaran briket akan semakin pendek. Nilai kalor yang tinggi menyebabkan briket mencapai suhu pembakaran yang maksimal serta suhu optimumnya cukup lama.

\section{Nilai Kalor}

Nilai kalor pada briket merupakan parameter yang sangat penting dalam menentukan kualitas briket. Menurut Almu et al [17], nilai kalor merupakan jumlah 
energi panas maksimal yang dikeluarkan oleh suatu bahan bakar melalui reaksi pembakaran. Grafik nilai kalor briket dapat dilihat pada Gambar 5 .

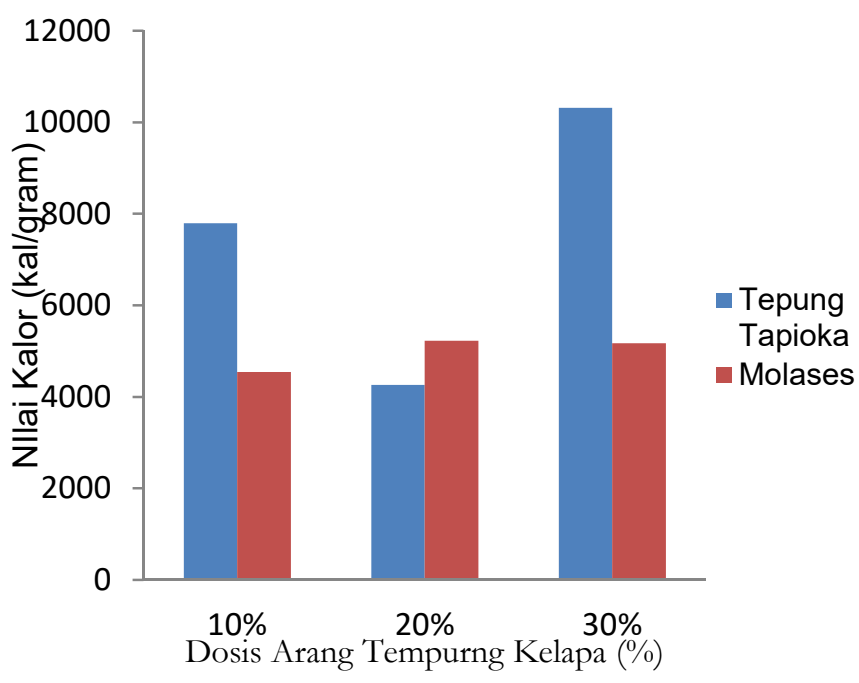

Gambar 5. Grafik nilai kalor briket

Berdasarkan Gamabr 5 diketahui nilai kalor briket tertinggi pada perekat tepung tapioka dengan dosis arang tempurung kelapa 30\% sebesar 10314,9 $\mathrm{kal} /$ gram, briket dengan nilai kalor terendah pada perekat tepung tapioka dengan dosis arang tempurung kelapa 20\% sebesar 4,263,9 kal/gram. Rendahnya nilai kalor pada briket dapat dipengaruhi oleh nilai kada abu hal ini dikarenakan kadar abu memiliki unsur silika yang berpengaruh kurang baik pada proses penyalaan briket. Sehingga semakin tinggi nilai kada abu akan menyebabkan nilai kalor semakin rendah (Sumangat dan Broto 2009) [18]. Nilai kalor pada perekat tepung tapioka memiliki nilai yang lebih tinggi dibandingkan perekat jenis molases, dikarenakan briket dengan perekat tepung tapioka briket memiliki nilai kerapatan, keteguhan tekan, kadar abu dan zat menguap yang tinggi. (Nasruddin dan Affandy, 2011) [19].

\section{Analisis ANOVA Dua Arah}

Analisis ANOVA dua arah dilakukan untuk mengetahui pengaruh dari setiap perlakukan briket terhadap karakteristik briket. Hasil analisis ANOVA 2 arah dapat diketahui pada Tabel 1.

Tabel 1. Analisis Anova dua arah

\begin{tabular}{|c|c|c|c|c|c|c|}
\hline Variabel Pengamatan & Sumber Variasi & $\begin{array}{c}\text { Derajat } \\
\text { bebas }\end{array}$ & $\begin{array}{c}\text { Jumlah } \\
\text { Kuadrat } \\
\text { (SS) }\end{array}$ & $\begin{array}{c}\text { Kuadrat } \\
\text { Tengah } \\
\text { (MS) }\end{array}$ & $\begin{array}{c}\text { F hitung } \\
(\mathrm{F})\end{array}$ & $\begin{array}{c}\text { F Tabel } \\
\text { (Ferit) }\end{array}$ \\
\hline \multirow[t]{4}{*}{ Kadar Air } & Perekat & 1 & 0,000150 & 0,000150 & 22,347 & 4,747 \\
\hline & Dosis & 2 & 0,000486 & 0,000243 & 36,157 & 3,885 \\
\hline & Interaksi & 2 & 0,000261 & 0,000130 & 19,397 & 3,885 \\
\hline & Galat & 12 & 0,000081 & 0,000007 & & \\
\hline \multirow[t]{4}{*}{ Kadar Abu } & Perekat & 1 & 0,000329 & 0,000329 & 1,509 & 4,747 \\
\hline & Dosis & 2 & 0,000428 & 0,000214 & 0,982 & 3,885 \\
\hline & Interaksi & 2 & 0,000504 & 0,000252 & 1,156 & 3,885 \\
\hline & Galat & 12 & 0,002614 & 0,000218 & & \\
\hline \multirow[t]{4}{*}{ Laju Pembakaran } & Perekat & 1 & 0,000000 & 0,000000 & 0,094 & 4,747 \\
\hline & Dosis & 2 & 0,000113 & 0,000057 & 13,732 & 3,885 \\
\hline & Interaksi & 2 & 0,000010 & 0,000005 & 1,208 & 3,885 \\
\hline & Galat & 12 & 0,000050 & 0,000004 & & \\
\hline \multirow[t]{4}{*}{ Suhu Pembakaran } & Perekat & 1 & 213,556 & 213,556 & 1,360 & 4,747 \\
\hline & Dosis & 2 & 73,000 & 36,500 & 0,232 & 3,885 \\
\hline & Interaksi & 2 & 97,444 & 48,722 & 0,310 & 3,885 \\
\hline & Galat & 12 & 1884,00 & 157,00 & & \\
\hline \multirow[t]{3}{*}{ Nilai Kalor } & Perekat & 1 & 9198645 & 9198645 & 1,889 & 18,51 \\
\hline & Dosis & 2 & 9022677 & 4511339 & 0,926 & 19 \\
\hline & Galat & 2 & 9739073 & 4869536 & & \\
\hline
\end{tabular}

Pada Tabel 1. Dapat diketahui pada parameter kadar air terdapat perbedaan yang nyata antara jenis perekat, dosis arang tempurung serta interaksi. Pada parameter laju pembakaran terdapat perbedaan yang 
nyata pada dosis arang tempurung kelapa. Dilihat dari nilia fhitung yang lebih besar dibandingkan dengan ftabel mana $\mathrm{H}_{1}$ diterima atau terdapat pengaruh perlakukan terhadap karakteristik briket. Kemudian dilakukan uji lanjutan dengan uji lanjutan Tukey dapat diketahui pada Tabel 2 dan Tabel 3.

Tabel 2. Uji Tukey Komparasi Jenis Perekat

\begin{tabular}{cccc}
\hline Uji & Komparasi & Beda absolut & Nilai kritis (HSD) \\
\hline Kadar Air & Molases dan Tapioka & 0,0057777 & 0,0034 \\
Laju Pembakaran & Molases dan Tapioka & 0,0000079 & 0,0027 \\
\hline
\end{tabular}

Pada Tabel 2 diketahui berdasarkan komparasi jenis perekat parameter kadar air memiliki nilai absolud yang lebih besar dibandingkan nilai kritis yang artinya $\mathrm{H}_{1}$ di terima atau jenis perekat berpengaruh pada nilai kadar air briket

Tabel 3. Uji Tukey komparasi dosis arang tempurung kelapa

\begin{tabular}{cccc}
\hline Uji & Komparasi & $\begin{array}{c}\text { Beda } \\
\text { absolut }\end{array}$ & $\begin{array}{c}\text { Nilai kritis } \\
\text { (HSD) }\end{array}$ \\
\hline \multirow{2}{*}{ Kadar Air } & 10 dengan 20 & 0,0042 & \\
& 10 dengan 30 & 0,0125 & 0,0034 \\
20 dengan 30 & 0,0083 & \\
Laju & 10 dengan 20 & 0,0016 & \\
Pembakaran & 10 dengan 30 & 0,0043 & 0,0027 \\
& 20 dengan 30 & 0,0059 & \\
\hline
\end{tabular}

Pada Tabel 3 diketahui uji kadar air dan laju pembakaran berdasarkan komparasi dosis arang tempurung kelapa memiliki nilai absolut yang lebih besar dibandingkan dengan nilai kritis artinya $\mathrm{H}_{1}$ di terima atau dosis arang tempurung kelapa berpengaruh pada nilai kadar air briket dan laju pembakaran.

\section{Komposisi Briket Terbaik}

Penentuan komposisi briket terbaik ditentukan dengan menggunakan metode skoring dengan kriteria briket dengan nilai kalor tertinggi, nilai kadar abu terendah, kadar air terendah, laju pembakaran tercepat, dan suhu pembakaran tertinggi. Hasil skoring briket dapat dilihat pada Tabel 4.

Tabel 4. Penentuan Komposisi Briket Terbaik dengan Metode Skoring

\begin{tabular}{|c|c|c|c|c|c|c|c|}
\hline \multirow{2}{*}{ Parameter } & \multirow{2}{*}{ Satuan } & \multicolumn{3}{|c|}{ Tapioka } & \multicolumn{3}{|c|}{ Molases } \\
\hline & & $10 \%$ & $20 \%$ & $30 \%$ & $10 \%$ & $20 \%$ & $30 \%$ \\
\hline \multirow[t]{2}{*}{ Nilai Kalor } & $\mathrm{kal} /$ gram & 7791,91 & 4263,96 & 10314,99 & 4544,73 & 5221,51 & 5175,50 \\
\hline & & (5) & (1) & (6) & (2) & (4) & (3) \\
\hline \multirow[t]{2}{*}{ Kadar Air } & $\%$ & 7,53 & 6,95 & 5,42 & 7,38 & 7,14 & 7,04 \\
\hline & & (2) & (5) & (6) & (2) & (3) & (4) \\
\hline \multirow{2}{*}{$\begin{array}{c}\text { Kadar Abu } \\
\text { Laju }\end{array}$} & $\%$ & 15,37 & 16,82 & 15,53 & 15,92 & 16,56 & 17,8 \\
\hline & & $(6)$ & $(2)$ & $(5)$ & (4) & (3) & (1) \\
\hline \multirow{2}{*}{$\begin{array}{c}\text { Laju } \\
\text { Pembakaran }\end{array}$} & $\mathrm{g} /$ menit & 0,028 & 0,025 & 0,032 & 0,025 & 0,03 & 0,03 \\
\hline & & $(6)$ & $(2)$ & (5) & (4) & (3) & $(1)$ \\
\hline \multirow{2}{*}{$\begin{array}{c}\text { Suhu } \\
\text { Pembakaran }\end{array}$} & ${ }^{\circ} \mathrm{C}$ & 549 & 544 & 533 & 538 & 544 & 543 \\
\hline & & (5) & (3) & (6) & (1) & (4) & (2) \\
\hline \multicolumn{2}{|c|}{ Skor } & 21 & 13 & 29 & 10 & 18 & 15 \\
\hline
\end{tabular}

Diketahui bahwa briket dengan komposisi terbaik briket dengan perekat tepung tapioka dan penambahan arang tempurung kelapa dosis 30\%, yang mendekati kriteria standar briket yakni nilai kalor tertinggi, kadar air terendah, laju pembakaran tertinggi dan suhu pembakaran tertinggi. 


\section{KESIMPULAN}

Komposisi briket terbaik ialah pada briket dengan perekat tepung tapioka dan dosis arang arang tempurung kelapa 30\%. Hal ini dapat dilihat dari nilai kalor tertinggi, kadar air terendah, laju pembakaran tertinggi dan suhu pembakaran tertinggi.

\section{DAFTAR PUSTAKA}

[1] Suhartoyo dan Sriyanto, "Efektifitas Briket Biomassa," Pros. SNATIF Ke-4, vol. 25 Juli, pp. 623-627, 2017.

[2] A. Ismayana, dan M. R. Afriyanto. "Pengaruh Jenis Dan Kada Bahan Perekat Pada Pembuatan Briket Blotong Sebagau Bahan Bakar Alternatif". Jurnal Teknik, vol. 21, no. 3, pp. 186-193, 2011.

[3] PT., Sido Muncul. "Handbook Laporan Sustainibility Report PT. Sido Muncul tahun 2019, Vol. 1". 2020

[4] E. Budi. "Tinjauan Proses Pembentukan dan Penggunaan Arang Tempurung Kelapa Sebagai Bahan Bakar Bahan Komponen Kdanungan Sifat Termal". vol. 14(C), pp. 25-29, 2011.

[5] Y. Ristianingsih, A. Ulfa, dan R. Syafitri, "Karakteristik Briket Bioarang Berbahan Baku Tdanan," J. Konversi, vol. 4, no. 2, pp. 16-21, 2015.

[6] Standart Nasional Indonesia. "Briket arang kayu", 2000.

[7] A. S. Lubis, M. Romli, dan G. Pari. " Mutu Biopelet dari Bagas, Kulit Tanah dan Pod. Kakao" Jurnal Teknologi Industri Pertanian. vol. 26, no. 1, 2016

[8] Y. Yuliah, S. Suryaningsih, dan K. Ulfi, "Penentuan Kadar Air Hilang dan Volatile Matter pada Bio-briket dari Campuran Arang Sekam Padi dan Batok Kelapa," J. Ilmu dan Inov. Fis., vol. 1, no. 1, pp. 51-57, 2017.

[9] D. Kurniawati, N. Diansyah Januardi, dan N. Subekhi, "Pengaruh Penambahan Serbuk Tongkol Jagung pada Pembuatan Biobriket dari Pelepah Pisang dengan Perekat Tetes Tebu," JMPM (Jurnal Mater. dan Proses Manufaktur), vol. 2, no. 1, pp. 1-7, 2018.

[10] R. Faijah. Fadila, dan Nurmila, "Perbdaningan Tepung Tapioka dan Sagu pada Pembuatan Briket Kulit Buah Nipah (Nypafruticans)" Jurnal Pendidikan Teknologi Pertanian, vol. 6, no. 2, 2020

[11] D. Kurniawati, N. Diansyah Januardi, dan N. Subekhi, "Pengaruh Penambahan Serbuk Tongkol Jagung pada Pembuatan Biobriket dari Pelepah Pisang dengan Perekat Tetes Tebu," JMPM (Jurnal Mater. dan Proses Manufaktur), vol. 2, no. 1, pp. 1-7, 2018.

[12] J. P. Pane, E. Junary, dan N. Herlina, "Pengaruh Konsentrasi Perekat Tepung Tapioka Dan
Penambahan Kapur Dalam Pembuatan Briket Arang Berbahan Baku Pelepah Aren (Arenga pinnata)," J. Tek. Kim. USU, vol. 4, no. 2, pp. 32-38, 2015.

[13] Y. A. Ristianingsih, Ulfa., dan R.. Syafitri. "Karakteristik Briket Bioarang Berbahan Baku Tdanan". Jurnal Konversi, vol. 4, no. 2, pp. 16-21. 2015.

[14] F. Rahmadani. Hamzah. dan F. H. Hamzah., "Pembuatan Briket Arang Daun Kelapa Sawit (Elaeisguineensis Jacq.) Dengan Perekat Pati Sagu," JOM Faperta UR, vol. 32, no. 6, pp. 514-520, 2017.

[15] A. Ismayana ,dan M. R. Afriyanto, "Pengaruh Jenis Dan Kada Bahan Perekat Pada Pembuatan Briket Blotong Sebagau Bahan Bakar Alternatif," J. Tek., vol. 21, no. 3, pp. 186-193, 2011.

[16] S. Jamilatun, "Sifat-Sifat Penyalaan dan Pembakaran Briket Biomassa, Briket Batubara dan Arang Kayu," J. Rekayasa Proses, vol. 2, no. 2, pp. 37-40, 2008.

[17] M. A. Almu, S. Syahrul, dan Y. A. Padang, "Analisis Nilai Kalor Dan Laju Pembakaran Pada Campuran Biji Nyamplung (Calopbyllm Inophyllum) Dan Abu Sekam Padi," Din. Tek. Mesin, vol. 4, no. 2, pp. 117-122, 2014.

[18] D. Sumangat dan W. Broto, "Jarak Pagar Sebagai Bahan Bakar Tungku," Bul. Teknol. Pascapanen Pertan., vol. 5, pp. 18-26, 2009.

[19] Nasruddin dan R. Affdany, "Karakteristik Briket Dari Tongkol Jagung Dengan Perekat Tetes Tebu Dan Kanji," J. Din. Penelit. Ind., vol. 22, no. 2, pp. 1-10, 2011. 